\title{
When the Money Stops: Fluctuations in Financial Remittances and Incumbent Approval in Central Eastern Europe, the Caucasus and Central Asia
}

Forthcoming in the American Political Science Review

\section{Katerina Tertytchnaya}

Department of Politics and International Relations

University of Oxford

Manor Road

Oxford OX1 3UQ

United Kingdom

katerina.tertytchnaya@politics.ox.ac.uk

\section{Catherine E. De Vries}

Department of Political Science \& Public Administration

Vrije Universiteit Amsterdam

De Boelelaan 1055

$1081 \mathrm{HV}$ Amsterdam

The Netherlands

c.e.de.vries@vu.nl

\section{Hector Solaz}

Department of Political Science \& Public Administration

Vrije Universiteit Amsterdam

De Boelelaan 1055

$1081 \mathrm{HV}$ Amsterdam

The Netherlands

h.solazsantos@vu.nl

David Doyle

Department of Politics and International Relations

University of Oxford

Manor Road

Oxford OX1 3UQ

United Kingdom

david.doyle@politics.ox.ac.uk 


\begin{abstract}
Fluctuations in the volume and the value of financial remittances received from abroad affect the livelihood of households in developing economies across the world. Yet, political scientists have little to say about how changes in remittances, as opposed to the receipt of remittance payments alone, affect recipients' political attitudes. Relying on a unique fourwave panel study of Kyrgyz citizens between 2010-2013 and a cross-sectional sample of 28 countries in Central Eastern Europe, the Caucasus and Central Asia, we show that when people experience a decrease (increase) in remittances, they become less (more) satisfied about their household economic situation and misattribute responsibility to the incumbent at home. Our findings advance the literature on the political consequences of remittance payments and suggest that far from exclusively being an international risk-sharing mechanism for developing countries, remittances can also drive fluctuations in incumbent approval and compromise rudimentary accountability mechanisms in the developing world.
\end{abstract}

\title{
Acknowledgements
}

Previous versions of this paper were presented at research seminars at the Institute of Advanced Studies in Toulouse, the London School of Economics, Pompeu Fabra University and the University of California, Los Angeles as well as the Annual Meeting of the Midwest Political Science Association. The authors would like to thank Jesse Acevedo, Faisal Ahmed, Ben Ansell, Laia Balcells, Michael Becher, Tilman Brück, Elias Dinas, Abel Escribà-Folch, Damir Esenaliev, Aina Gallego, Miriam Golden, Carlo Horz, David Leblang, Lucas Leemann, Barry Maydom, Covadonga Meseguer, Lucas Novaes, Karine Van Der Straeten, Mariken van der Velden, Cesar Zucco as well as four anonymous reviewers and the editor at the American Political Science Review for their constructive comments. 


\section{Introduction}

For developing world economies, financial remittances, in the form of private-to-private income transfers sent by a family member abroad to a relative in their country of origin, are now a major source of capital. In 2015 alone, worldwide remittances exceeded 601 billion US Dollars and of that amount, 441 billion went to developing countries (Ratha et al. 2016). This is a sum equivalent to three times the size of all global aid flows. Development economists have long been interested in the economic impact of these income transfers. Although a contentious debate exists about the relationship between remittances and economic growth (e.g. Page and Plaza 2006), many economists have suggested that remittances act as an important international risk-sharing mechanism (e.g. Yang and Choi 2007). This perspective however, is largely based on the assumption that remittance payments either remain stable over time, or that they increase in response to negative shocks in migrant sending economies. But what happens if remittance flows suddenly change? How do fluctuations in remittances influence the political attitudes of recipients?

In this study, we explore how fluctuations in remitted income affect support for the incumbent in remittance-receiving countries. Building on a small number of studies that have linked remittances to economic voting (Bravo 2012; Germano 2013; Ahmed 2017) and recent work on competence misattribution in developing countries (Campello and Zucco 2016), we contend that changes in remittances influence economic assessments and incumbent approval in recipient countries. Specifically, we expect that when remittance inflows increase, economic evaluations and incumbent approval will also increase, but when these payments decline, recipients will punish incumbents. Our argument echoes recent work in economic voting that highlights the importance of pocketbook assessments for incumbent approval (e.g. Manacorda et al. 2011; Pop-Eleches and Pop-Eleches 2012). By relying on their pocketbooks to inform their evaluations of government performance however, remittance recipients may 
be rewarding or punishing incumbents at home for economic developments abroad, in remittance sending economies, that are largely outside of the incumbent's control.

We are able to test these expectations by leveraging a unique four-wave panel study of Kyrgyz citizens between 2010-2013 that allows us to carefully identify how fluctuations in remittances influence economic assessments and incumbent approval in Kyrgyzstan (Life in Kyrgyzstan, LiK). An additional instrumental variable estimation allows us to address concerns about endogeneity. We bolster the external validity of our findings by supplementing our analyses with cross-national data from 28 countries in Central Eastern Europe, the Caucasus and Central Asia covered in the 2010 European Bank for Reconstruction and Development (ERBD) Life in Transition surveys (LiTS). The results of our analyses strongly support our main theoretical contention; they establish a robust link between fluctuations in remittances, economic assessments and incumbent approval.

Our findings have a number of important implications. Firstly, while a large literature on the economic ramifications of remittances exists, there is very little work on the political dynamics of these capital inflows. Having said that, some recent work has begun to explore the political effects of remittances at the national level (Abdih et al. 2012, Tyburski 2012; Aparicio and Meseguer 2012; Pfutze 2014, O’Mahony 2013; Ahmed 2012, Escribà-Folch et al. 2015; Chaudhry 1997; Singer 2012; Doyle 2015; Leblang 2017), but we still only have a small number of studies that explore the effect of financial remittances on individual-level political attitudes and behavior (Meseguer et al. 2016; Germano 2013, Bravo 2012). While some of this work has connected remittances to economic voting (Bravo 2012; Germano 2013; Ahmed 2017), only the work of Acevedo (2016) has considered, although not explicitly tested, how fluctuations in remitted income might affect the political attitudes of recipients with regard to demand for welfare. No work in political science has yet examined 
how fluctuations in remittance inflows might affect recipients' political attitudes in general, and support for incumbents in particular.

This paper is also relevant for work on economic voting (e.g. Kramer 1971, Fiorina 1981) and competence misattribution in developed and developing countries (e.g. Duch and Stevenson 2008; Healy, et al. 2010). While some evidence suggests that voters in Europe can disentangle competence from exogenous shocks, i.e. events largely outside of the control of incumbents (Duch and Stevenson 2008), recent work has challenged this assumption for lowinformation, developing country contexts (Campello and Zucco 2016). Traditional accounts of economic voting conclude that rational voters should only sanction the incumbent when economic performance is the product of government competence (e.g. Duch and Stevenson 2008). Yet in developing countries, where party systems are often weak and party labels have little meaning (Lupu 2016), economic outcomes and assessments, even if largely driven by exogenous factors, may be the only signal or source of information about incumbent competence that voters have and may serve as the basis for a calculated economic vote (Campello and Zucco 2017).

Rewarding or punishing incumbents for developments abroad may be a rational strategy for voters, especially in developing economies characterized by high volatility and paucity of information. Accountability mechanisms however, which are often rudimentary in these contexts, could erode even further as a result; it constitutes a form of competence misattribution (see Campello and Zucco 2017). For electoral accountability to function properly, voters need to reward, or punish, incumbents for outcomes for which they are primarily responsible (Kayser and Peress 2012). In many ways, investigating whether voters update their incumbent evaluations in response to fluctuations in remittances provides an excellent test of the misattribution mechanism. Existing research argues that remittances are largely outside of the control of governments in migrant home countries (Bravo 2016) and 
when incumbent popularity is shaped by remittance inflows from abroad, this may be a political manifestation of economic dependency (e.g. Wibbels 2006).

We proceed as follows. The next section discusses existing research on the political consequences of remittances, before presenting the main argument of our work. We then introduce our case selection, data and analysis of the LiK panel data, and LiTS crosssectional surveys. The final section concludes.

\section{The Political Consequences of Remittances}

Development economists have long been concerned with the economic effects of remittances. Their work highlights the role of remittances in reducing poverty, illiteracy and infant mortality (for an overview, see Fajnzylber et al. 2008). There is also a well-documented debate about the effect of remittances on economic growth in developing economies (e.g. Page and Plaza 2006). Very little work however, has explored the political effects of remittances. We have a vast literature on the political consequences of immigration in migrant receiving states (e.g. Cornelius and Rosenbulm 2005), but know very little about the political effects that remittances might exert on the countries or individuals that receive them.

Nonetheless, in recent years, a number of studies have begun to explore the effect of remittances and migration on the politics of remittance receiving, and migrant sending, states. This work has demonstrated that remittances can affect exchange rate policy (Singer 2010), dual citizenship requirements (Leblang 2017), and public accountability (Abdih et al. 2012; Tyburski 2012; Aparicio and Meseguer 2012), together with the linkage strategies adopted by political parties, notably clientelism (Pfutze 2014; O’Mahony 2013). Evidence suggests that remittances can prolong (Ahmed 2012) and hinder (Escribà-Folch et al. 2015) the survival of autocratic regimes and they can also shape the level, and type, of government expenditures 
(Chaudhry 1997; Ahmed 2012; Singer 2012; Doyle 2015). The majority of this work is at the macro-level.

There are only a few exceptions to this general trend. A number of studies have explored the effect of social remittances, that is, the norms and ideas that migrants observe in their host country and transmit to family members in their country of origin, on individual level political behavior and preferences (e.g. Levitt 2001). This work suggests that social remittances can lead to higher rates of non-electoral political participation and more critical evaluations of democracy (Pérez-Armendáriaz and Crow 2010), higher rates of political activity and political interest (Córdova and Hiskey 2015) and support for a more enhanced role for the state (Meseguer et al. 2016).

Less work studies the effect of financial remittances on the political behavior and attitudes of those that receive them. Given the scale of these transfers, in some contexts they can be as large as the national median income, and given that they are generally untaxed and go directly into the hands of the individuals that receive them, this would seem to be an oversight, particularly as we now know how important personal economic evaluations can be for electoral behavior (Kramer 1971; Fiorina 1981; Duch and Stevenson 2008). While Doyle (2015), Meseguer et al. (2016) and Acevedo (2016) have examined the effect of financial remittances on individual attitudes towards taxation and the state, only three authors have explicitly linked the receipt of financial remittances with the economic vote.

In the first study of this kind, Germano (2010) demonstrated that remittance recipients in Mexican municipalities, due to the transnational social safety net effect of remittances, are less likely to identify the economy as a pressing problem relative to non-recipients and to have fewer economic grievances. Consequently, the more positive egocentric and sociotropic outlook of remittance recipients means that they are less likely to oppose incumbent politicians (e.g. Germano 2013). In a similar vein, Bravo (2012) has demonstrated that in 
Latin American countries, financial remittances positively influence presidential approval amongst recipients and that this effect operates through more favorable egocentric and sociotropic evaluations of the economic situation. Ahmed (2017), again for a Latin American sample, has demonstrated that at high levels of dissatisfaction with the incumbent, a remittance recipient is more likely to vote for that incumbent, relative to a non-recipient. What is particularly interesting about these studies is the fact that, as Bravo (2012) has suggested, remittances are an exogenous capital flow, over which the incumbent government, in most situations, has little control. In this work, remittances appear to be operating through a mechanism consistent with pocketbook voting effects. It is from these studies that we take our cue.

\section{Remittances and Economic Voting}

One of the largest bodies of work in political science is concerned with the importance of the economic vote. Beginning with Downs' (1957) classic assertion that individuals will choose parties to best maximize their personal utility, work in this vein has demonstrated that support for the incumbent is based on voter evaluations of economic performance: when economic performance is deemed to be good, incumbents are rewarded and when economic performance is deemed bad, incumbents are punished or sanctioned (e.g. Kramer 1971; Fiorina 1981). This economic voting model has more sophisticated variants; most notably, competence models, which argue that voters go beyond a reward-punishment calculus and instead seek to select the most competent candidate, based on expectations developed with the available economic data they have observed (e.g. Stigler 1973; for an overview, see Duch and Stevenson 2008, 12-16). For this reason, economic voting comes with significant normative implications. It suggests that even in low-information environments with weak party systems, voters can assign responsibility for economic outcomes to the actions of 
incumbents, thereby establishing a chain of democratic accountability (Stokes 2001). In fact, across new democracies, evidence suggests that the economic vote is prevalent from Latin America (Singer 2013) to Africa (Posner and Simon 2002) to Eastern Europe (Roberts 2008).

Voters however, are not always able to establish a coherent link between economic outcomes and incumbent action. Existing research shows that in developing democracies, support for incumbents is largely determined by economic and political developments abroad, such as commodity price shocks (e.g. Leigh 2009; Monteiro and Ferraz 2012). Focusing on Latin America for example, Campello and Zucco (2016) provide evidence that voters misattribute responsibility for economic outcomes to incumbents. They develop a 'Good Economic Times' index based on commodity prices and US interest rates, which are exogenous to the control of Latin American governments. They demonstrate that this index can help explain the re-election of incumbents and presidential popularity. When times are good, incumbents are rewarded and when times are bad, incumbents are punished.

In many respects, remittances are an even better test of attribution in economic voting. Remittances are the "epitome of private transfers" (Bravo 2012, 6). They go straight into the hands of the individuals that receive them, often get transferred outside of formal bank channels, and for many countries in the world, lie largely outside of the incumbent's control. For this reason, existing work considers remittances as an excellent identification strategy to test whether voters hold incumbents accountable for events beyond their control (Bravo 2012). While it is possible for governments to control the inflow of remittances, mainly through some form of tax on remitted income, or schemes to encourage migrants to remit more, or through manipulation of the official exchange rate (e.g. O'Neill 2001), the regulation of remittances does not come cheap. ${ }^{1}$ Where taxes on remittances have been

\footnotetext{
${ }^{1}$ Examples of taxes on remittances include a five per cent tax on remittances in Vietnam (which was removed in 1997), a state cross-border tax on remittances in Tajikistan (removed
} 
introduced in the past, they have tended to drive cash flows into informal channels and blackmarket activity (see Mohapatra, et al. 2012) and as such, remittances are usually untaxed. For example, in Kyrgyzstan, the case we are interested in here, the government has not manipulated the exchange rate during the period covered in our data (2010-2013), it has not engaged in any form of remittance incentive scheme, nor has it attempted to tax remittance inflows (Slay 2015).

Focusing on remittance payments alone, an influential literature shows that they not only increase the general consumable income of households that receive them (e.g. Barajas et al. 2009), but also provide recipients with a social safety net that can insure them against economic shocks (Chaudhry 1997; Doyle 2015; Germano 2013; Yang and Choi 2007), thereby increasing their financial stability and reducing their economic grievances (Germano 2013). The net effect of this financial stability and greater consumption power is more positive egocentric and sociotropic economic evaluations. In turn, recipients' evaluations of the incumbent government will improve. Bravo (2012), Germano (2013) and Ahmed (2017) provide evidence that this is exactly what happens in Latin America. Across the Americas (Bravo 2012; Ahmed 2017), and in Mexican municipalities (Germano 2013), remittance recipients exhibit greater support for incumbents relative to non-recipients, an effect that operates through the positive egocentric and sociotropic economic evaluations of recipients.

We do not take issue with these arguments. We agree that the insurance and consumption effects of remittances are likely to increase economic optimism and result in support for the incumbent. In fact, in Table 1, we broadly follow Bravo's (2012) analysis

in 2003), an overseas document stamp tax in the Philippines (removed for workers in 1995) and the tax that the Indian government levies on fees from money transfer agents, but not on actual remittance flows (e.g. Mohapatra, et al. 2012). When Vietnam and Tajikistan removed their taxes on remittances, official flows significantly increased. 
with data from 26 countries in Central Eastern Europe, the Caucasus and Central Asia, drawn from the 2006 wave of the $\operatorname{LiTS}^{2}$ (summary statistics are provided in Section A.2 of the Supporting Information (SI)). With a simple dichotomous measure of whether a respondent receives remittances or not, two-level multilevel models presented below, demonstrate that, similar to Bravo's (2012) results, financial remittances increase satisfaction with household (Model 1) and national (Model 2) economic conditions. The effect of remittances on trust towards the country's president in Model 3 is also positive, and statistically significant. The effect of remittances on political evaluations in Model 4 remains robust, even after we control for economic satisfaction at the household, and national level (for more information see page 13 of the SI). Yet, what happens when remittance inflows change?

\footnotetext{
${ }^{2}$ These countries are: Albania, Armenia, Azerbaijan, Bosnia-Herzegovina, Bulgaria, Croatia, the Czech Republic, Estonia, Georgia, Hungary, Kazakhstan, Kyrgyzstan, Latvia, Lithuania, Moldova, Montenegro, FYR Macedonia, Poland, Romania, Russia, Serbia, Slovakia, Slovenia, Tajikistan, Ukraine and Uzbekistan.
} 
Table 1 Remittances, economic assessments, and support for the president

\begin{tabular}{|c|c|c|c|c|}
\hline & $\begin{array}{c}\text { Pocketbook } \\
\text { Assessments } \\
\text { Model (1) } \\
\end{array}$ & $\begin{array}{c}\text { Sociotropic } \\
\text { Assessments } \\
\text { Model (2) } \\
\end{array}$ & $\begin{array}{c}\text { Trust in the } \\
\text { President } \\
\text { Model (3) } \\
\end{array}$ & $\begin{array}{c}\text { Trust in the } \\
\text { President } \\
\text { Model (4) } \\
\end{array}$ \\
\hline Remittances & $\begin{array}{c}0.135 * * * \\
(0.041)\end{array}$ & $\begin{array}{l}0.048 * \\
(0.027)\end{array}$ & $\begin{array}{c}0.070 * * \\
(0.032)\end{array}$ & $\begin{array}{l}0.056^{*} \\
(0.031)\end{array}$ \\
\hline Pocketbook & & & & $\begin{array}{c}0.027 * * * \\
(0.005)\end{array}$ \\
\hline Sociotropic & & & & $\begin{array}{c}0.230 * * * \\
(0.008)\end{array}$ \\
\hline Employed & $\begin{array}{c}0.122 * * * \\
(0.022)\end{array}$ & $\begin{array}{l}-0.019 \\
(0.015)\end{array}$ & $\begin{array}{c}0.026 \\
(0.018)\end{array}$ & $\begin{array}{c}0.028 \\
(0.017)\end{array}$ \\
\hline Education & $\begin{array}{c}0.289 * * * \\
(0.018)\end{array}$ & $\begin{array}{c}0.015 \\
(0.012)\end{array}$ & $\begin{array}{c}0.046^{* * *} \\
(0.014)\end{array}$ & $\begin{array}{c}0.035 * * * \\
(0.014)\end{array}$ \\
\hline Age & $\begin{array}{c}-0.005 * * * \\
(0.001)\end{array}$ & $\begin{array}{l}-0.001 \\
(0.000)\end{array}$ & $\begin{array}{c}0.005 * * * \\
(0.001)\end{array}$ & $\begin{array}{c}0.005^{* * *} \\
(0.001)\end{array}$ \\
\hline Male & $\begin{array}{c}-0.024 \\
(0.020)\end{array}$ & $\begin{array}{c}0.010 \\
(0.013)\end{array}$ & $\begin{array}{c}-0.041 * * * \\
(0.016)\end{array}$ & $\begin{array}{c}-0.043^{* * *} \\
(0.016)\end{array}$ \\
\hline Wealth & $\begin{array}{c}0.288 * * * \\
(0.007)\end{array}$ & $\begin{array}{c}0.065 * * * \\
(0.004)\end{array}$ & $\begin{array}{c}0.028 * * * \\
(0.005)\end{array}$ & $\begin{array}{c}0.005 \\
(0.005)\end{array}$ \\
\hline Rural & $\begin{array}{c}0.026 \\
(0.023)\end{array}$ & $\begin{array}{c}0.039 * * * \\
(0.015)\end{array}$ & $\begin{array}{c}0.121 * * * \\
(0.018)\end{array}$ & $\begin{array}{c}0.112 * * * \\
(0.018)\end{array}$ \\
\hline Metropolitan & $\begin{array}{l}-0.042 \\
(0.029)\end{array}$ & $\begin{array}{c}-0.095^{* * * *} \\
(0.019)\end{array}$ & $\begin{array}{c}-0.139 * * * \\
(0.022)\end{array}$ & $\begin{array}{c}-0.116^{* * *} \\
(0.022)\end{array}$ \\
\hline Growth & $\begin{array}{l}-0.026^{*} \\
(0.015)\end{array}$ & $\begin{array}{l}0.027^{*} \\
(0.014)\end{array}$ & $\begin{array}{c}0.051 * * \\
(0.021)\end{array}$ & $\begin{array}{c}0.046^{* *} \\
(0.019)\end{array}$ \\
\hline Constant & $\begin{array}{c}3.419 * * * \\
(0.159)\end{array}$ & $\begin{array}{c}2.243 * * * \\
(0.147)\end{array}$ & $\begin{array}{c}2.325 * * * \\
(0.213)\end{array}$ & $\begin{array}{c}1.718 * * * \\
(0.193)\end{array}$ \\
\hline Log Likelihood & -47618 & -36722 & -41312 & -40778 \\
\hline AIC & 95259 & 73468 & 82649 & 81585 \\
\hline $\mathrm{BIC}$ & 95357 & 73566 & 82747 & 81699 \\
\hline Individuals & 25,438 & 25,438 & 25,438 & 25,438 \\
\hline Countries & 26 & 26 & 26 & 26 \\
\hline
\end{tabular}

Notes: The table reports coefficients from hierarchical linear models (HLM) with standard errors in parentheses. The baseline category for settlement status (rural and metropolitan) is urban. For more information see Table B.1 and page 13 of the Supporting Information (SI) as well as see Tables C.1-C.3 for robustness checks. *** significant at $\mathrm{p} \leq 0.01,{ }^{* *} \mathrm{p} \leq .05,{ }^{*} \mathrm{p} \leq 0.1$ level. Source: EBRD Life in Transition Survey (LiTS), 2006

\section{Changes in Remittances and Incumbent Approval}

Remittances do not always reach recipient households at the same time and in the same amount, and changes in the frequency and value of remittances will affect the livelihood of 
households in developing economies across the world. During periods of economic contraction in migrant host economies, remittance payments are likely to fall due to changing migration flows, currency depreciation, or efforts by migrants to cut costs (Mohapatra and Ratha 2010). In the midst of the global financial crisis for example, the World Bank estimated that remittance flows to developing countries declined by 6 per cent between 2008 and 2009. What are the political effects of changes in remittance flows?

We argue that recipients who experience a decline in remittances become less satisfied with their economic situation, thereby undermining their support for the incumbent. Conversely, when remittances increase, the economic evaluations of recipients will improve, resulting in an increase in incumbent support. In other words, remittance recipients are rewarding or punishing incumbents for economic developments in migrant receiving economies that are largely outside of the control of politicians at home. While this may be a type of pocketbook voting, it also represents a form of misattribution with normative implications for democratic accountability in remittance dependent states. Punishing or rewarding incumbents for events outside their control may distort the economic vote as an instrument of accountability as it will undermine the direct link between government action, voters and electoral sanctions (Campello and Zucco 2017). For remittance receiving countries, incumbent approval will be subject to economic conditions in countries elsewhere. If countercyclical, remittances may 'buffer' recipients from the vagaries of the economy and bolster support for incumbents, but such effects could also dampen incumbent incentives to invest in welfare provisions (Doyle 2015) and encourage governments to divert income into patronage instead (Ahmed 2012). Declines in remittances, caused by downturns in economies abroad, may exacerbate economic grievances among the electorate and lead to poor evaluations of the incumbent for events not necessarily under their control. In some senses 
then, the flow of remittances to the developing world would appear to be a political manifestation of economic dependency (e.g. Wibbels 2006).

Moreover, while we agree with Bravo (2012) that remittances are an excellent identification strategy to test how individuals attribute responsibility for shocks to their income and economic security, we think we can go one step further. Bravo (2012) argues that the bias introduced by unobserved household and individual heterogeneity is likely to bias results downwards, given that those who migrate are most likely to come from households with more negative evaluations of the incumbent and status quo. ${ }^{3}$ Our panel data allows us to overcome some of the potential sources of bias by employing a within-subject design. By limiting our analysis to remittance recipients alone, we are also able to address concerns regarding the unobserved differences between households that receive remittances and those that do not.

\section{Background and Case Selection}

In the ensuing sections, we provide a detailed test of whether and how fluctuations in remitted income affect political attitudes. We first illustrate our argument with the case of Kyrgyzstan. Leveraging a unique four-wave panel study of Kyrgyz citizens between 20102013, the LiK surveys, we are able to carefully identify how changes in remittances affect variation in incumbent approval. In a second step, we turn to cross-sectional survey data from Central Eastern Europe, the Caucasus and Central Asia, collected in the aftermath of the

\footnotetext{
${ }^{3}$ Of course, it is possible that in a global or regional crisis, recipients may experience a decline in their remitted income and still blame their government for their perceived role in the wider regional crisis, above and beyond any changes in their remittances.
} 
Great Recession in 2008-2010. Specifically, we rely on the 2010 LiTS that includes survey data for 28 countries in the region. ${ }^{4}$

Central Eastern Europe, Central Asia, and the Caucasus provide a useful context for exploring how fluctuations in financial remittances affect political attitudes. For many of the countries in the region, remittances are one of the most important sources of external financing after foreign direct investment. In the mid-2000s for example, financial remittances were equivalent to 20 per cent of GDP in Moldova, Bosnia and Herzegovina and over 10 per cent in Albania and Armenia. Yet, during the Great Recession of 2008-2010, the period from which the survey evidence we rely on is drawn, remittances became a channel through which the crisis was transmitted, not mitigated. The deterioration in the economy of migrant host countries caused official remittance flows in Central Eastern Europe and Central Asia to fall by 23 per cent on average (Ratha, et al. 2010). Relying on World Bank data, Figure 1 provides an overview of how the inflow of remittances (as a percentage of GDP) fluctuated between 2008 and 2009 in the region.

\footnotetext{
${ }^{4}$ The countries included in the analysis are: Albania, Armenia, Azerbaijan, Belarus, BosniaHerzegovina, Bulgaria, Croatia, the Czech Republic, Estonia, Georgia, Hungary, Kazakhstan, Kosovo, Kyrgyzstan, Latvia, Lithuania, Moldova, Montenegro, FYR Macedonia, Poland, Romania, Russia, Serbia, Slovakia, Slovenia, Tajikistan, Ukraine and Uzbekistan.
} 


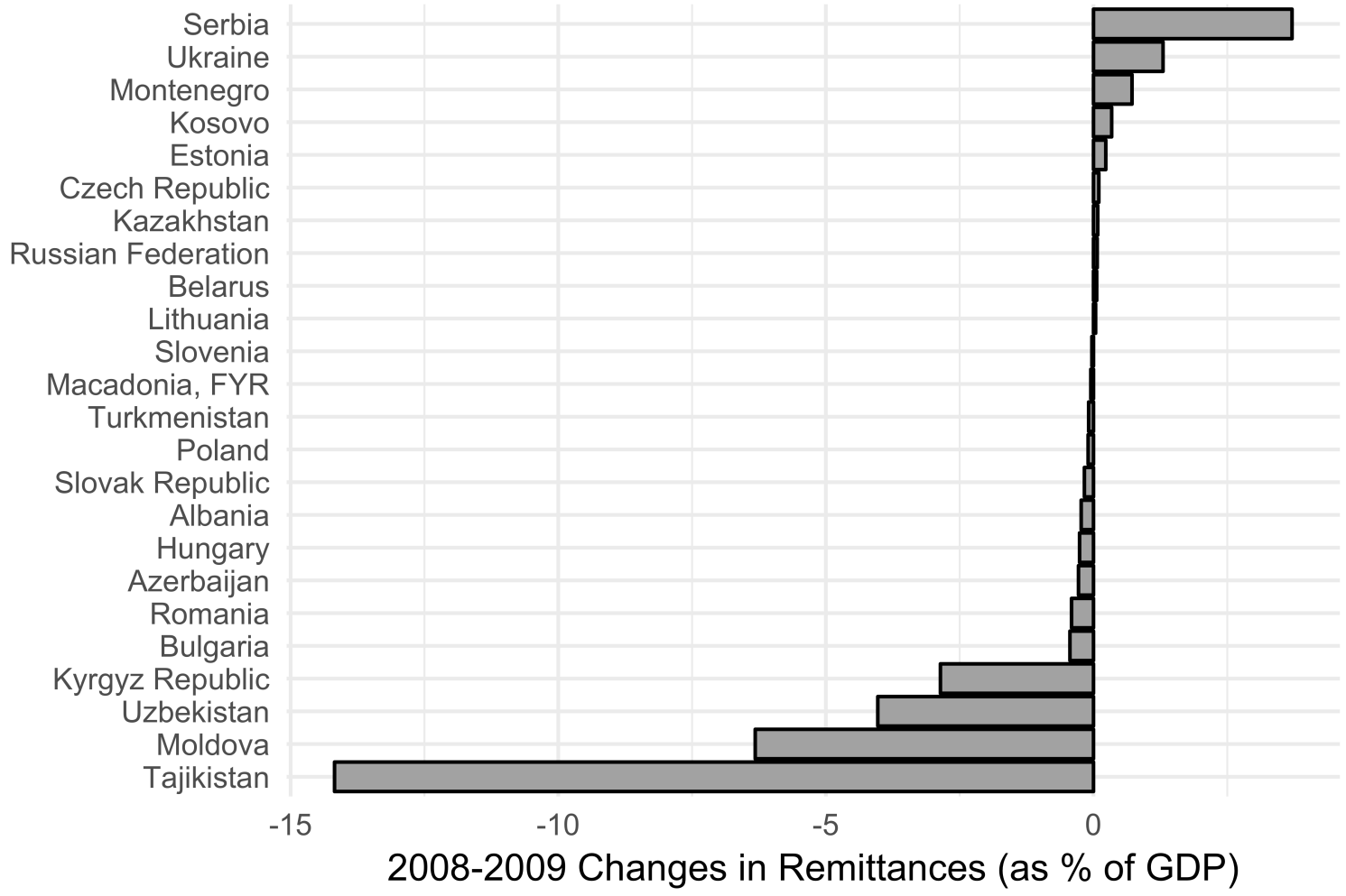

Notes: The Figure shows changes in the share of personal remittances received as a percentage of a country's overall GDP between 2008 and 2009. Source: World Bank, World Development Indicators.

Figure 1 Fluctuations in remittances inflow (as percentage of GDP) between 2008 and 2009

The Kyrgyz economy is one of the most remittance-dependent economies in the world. From 2011 to 2014, the flows of financial remittances were as large as about one-third of the country's GDP (World Bank 2017). At the aggregate level, workers' remittances, which represent the most important financing flow in the country's balance of payments, have covered a large part of the national trade and budget deficits. In just three years for example, Kyrgyzstan's budget deficit dropped from 13.7 per cent of GDP in 2008 to 6.4 per cent in 2011 (International Monetary Fund 2016).

At the same time, dependence on remittances exposes the Kyrgyz economy to developments abroad, especially in Russia, where the largest share of the country's migrant population seeks employment. It is estimated for example, that about 97 per cent of all remittance flows to Kyrgyzstan originate from the Russian Federation. When remittance 
outflows from Russia to the Commonwealth of Independent States dropped by 33 per cent during the first three quarters of 2009, Kyrgyzstan was one of the first countries to experience the consequences (Mohapatra and Ratha 2010). According to World Bank estimates, in 2009, some Central Asian (Kazakhstan, Tajikistan, Kyrgyzstan) and Eastern European countries (Romania, Moldova) experienced reductions of one half, to one third, of their 2008 remittance levels. This decline in remitted income recovered, before worsening again. The overall flow of remittances from Russia increased from 1008 million US Dollars in 2010 to 1759.7 million in 2013, before suffering another drop due to the depreciation of the Russian currency in 2014. Figure 2, which relies on evidence from the World Bank Development Indicators, summarizes these trends, showing how the remittances that Kyrgyzstan received (as a percentage of the country's GDP) fluctuated during the period 2002-2015.

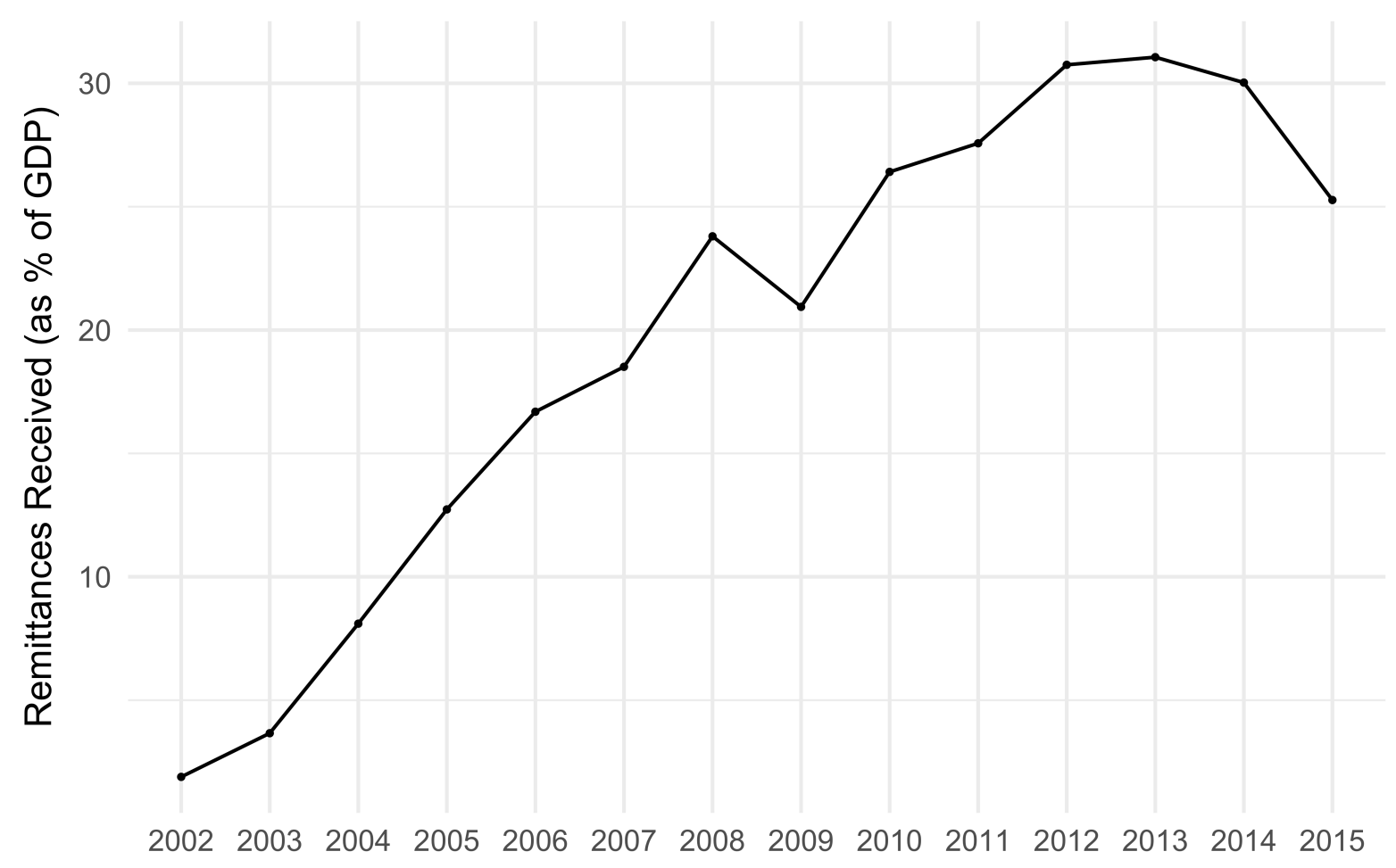

Notes: The Figure shows fluctuations in the share of remittances received in Kyrgyzstan as a percentage of the country's GDP in the 2002-2015 period. Source: World Bank, World Development Indicators.

Figure 2 Personal remittances received (as percentage of GDP) in Kyrgyzstan, 2002 - 2015 
In the time-period covered in the LiK surveys between 2010 and 2013, the Kyrgyz economy experienced a period of stable growth. Across all four years, Kyrgyzstan's GDP was around 6 billion US Dollars. During the period under analysis, the Kyrgyz government did not engage in any policy to either limit or control migration, nor any policy to actively encourage remittances and investment in Kyrgyzstan, such as diaspora bonds. The Kyrgyz government has never implemented a formal tax on remittances, while the official exchange rate is allowed to float freely (Slay 2015). In the second half of 2014, the Central Bank did use official reserves to prop up the Som-US Dollar exchange rate, which caused an appreciation of the Som against the Ruble. This led to an appreciating and overvalued SomRuble rate and given 90 per cent of remittances to Kyrgyzstan come from Russia, this had a deleterious effect on remittance inflows (Slay 2015). However, this occurred after the period covered by our panel (2010-2013). In fact, during the period of our panel remittance inflows actually increased. What is more, the increasing use of technology, such as mobile and internet transfers, is making it even more difficult for governments to exert control over remittance inflows (Vieira 2017). As such, we think it reasonable to suggest that remittances are largely exogenous in the case of Kyrgyzstan as the Kyrgyz government was not actively manipulating or controlling remittance inflows.

The period covered in the LiK surveys captures important variation in political developments. In 2010, President Bakiyev was violently overthrown and vicious inter-ethnic clashes escalated across the country. Violent riots in the spring of 2010 were associated with a collapse in trust in government institutions. According to evidence from the 2010 LiTS survey, Kyrgyzstan ranked in the bottom ten of transition countries in terms of trust in the President and the national government (EBRD 2010, 83). Yet, during the same year, Kyrgyzstan adopted a new constitution, and held the most free and fair election contest that took place in Central Asia on record (Freedom House 2010). The new leadership undertook 
reforms to liberalize the political system, combat corruption, and the country enjoyed a period of relative stability as its new parliamentary system began to function. A new election held in 2011 brought president Atambayev to power with an impressive 63 per cent of the vote. Although over the 2010-2012 period the Kyrgyz parliament produced four different ruling coalitions, reforms to combat corruption were introduced. The level of corruption in Kyrgyzstan declined significantly since the ousting of former president Bakiyev (Freedom House 2014). The stable growth that the Kyrgyz economy experienced since 2010, and political renewal in the years covered in the surveys, stacks the deck against finding declines in incumbent trust and support over the 2010 to 2013 period under investigation here.

\section{The Life in Kyrgyzstan Surveys}

The first part of the analysis relies on panel survey data from the 2010, 2011, 2012 and 2013 waves of the LiK survey (Brück et al. 2014). The survey tracks the same 3,000 households in all seven Kyrgyz oblasts (regions) and the two cities of Bishkek and Osh. The data are representative at both the national and regional level. 81.6 per cent of all 3000 households identified in the original sample in 2010 participated in all four waves. We restrict our sample to adults only (for more information on the LiK survey see section A1 of the SI). In 2010, 10.1 per cent of households received financial remittances, 12.3 per cent in 2011, 12.5 per cent in 2012 and 12.3 per cent in 2013. Households received their remitted income in four different currencies across the waves: 54.2 per cent of households received remittances in Kyrgyz Som, 39.6 per cent in Russian Rubles, 5.5 per cent in US Dollars, and 0.7 per cent in Euros. Given that we are interested in the political consequences of fluctuations in remittances, our analyses focus on remittance recipients only. Between 2010 and 2011, 67.3 per cent of remittance recipients experienced a change in the amount or frequency of money 
received, 63.6 per cent experienced a change between 2012 and 2011, and 63.1 per cent between 2012 and 2013.

We explore the political effects of fluctuations in remittances by relying on three different measures: 1) changes in the amount of remitted income received between survey waves, 2) changes in the frequency of remittances received between survey waves, and 3) changes in a Remittance Index that combines information about both the amount and regularity of remittances (Germano 2010). By moving beyond a simple dichotomous measure of receiving remittances or not, these measures allow us to capture important variation in the dynamics of remittance flows.

Our first measure captures changes in the amount of remitted income across the different survey waves. It relies on respondents' answers to two survey questions. First, respondents were asked: 'During the last 12 months, did you receive any money from abroad sent by migrants who are members of this household?' Second, respondents who indicated that they received money sent by migrants were asked 'How much money did household migrants send over the last 12 months?' The variable Change in Amount of Remittances ${ }_{t-(t-1)}$ subtracts the amount of money received in wave $\mathrm{t}-1$ from the amount of money received at wave $t$ for each respondent. It therefore captures the change in the amount of remitted income received by each respondent between survey waves. Respondents were asked to report the amount of money in the currency in which they received it, that is to say Kyrgyz Som, Russian Rubles, US Dollars, or Euros. In order to ensure that the magnitude of changes in the amount of remitted income are comparable, we transferred all amounts into Kyrgyz Som by using the average exchange rate over the year (for more detailed information see Table A.4 of the SI). The variable Change in Amount of Remittances ${ }_{t-(t-1)}$ varies between -23.4 and 35.7, i.e. from 234 to 357 thousand Som. With the 2010-2013 average Som to US Dollar exchange 
rate, these changes approximately vary between a maximum decrease of 5 and maximum increase of 8 thousand US Dollars respectively.

Our second measure captures the changes in the frequency with which respondents receive remittances across survey waves. It relies on respondents' answers to the following survey question: 'How many times within the last 12 months did migrants send/bring money?' This question was asked only to those respondents who indicated that they received money from migrants abroad over the last 12 months. Respondents were given six answer categories: '1) once, 2) 2-3 times, 3) 4-5 times, 4) 6-10 times, 5) 11-12 times, and 6) more than 12 times.' The variable Change in Frequency of Remittances $t-(t-1)$ subtracts the frequency with which remittances were received in wave $t-1$ from the frequency in wave $t$ for each respondent. Hence, the variable captures the change in the frequency with which respondents received remittances from abroad between each survey wave. The variable Change in Frequency of Remittances ${ }_{t-(t-1)}$ ranges from a minimum value of -5) to a maximum value of 5).

Our third measure relies on changes in a Remittance Index. This index taps into the degree to which remittances are a substantial and reliable source of income. While the continuous measures of remittances used here are an improvement on categorical measures, they might not capture the extent to which these financial flows constitute a substantial and reliable source of income. To overcome some of these issues, Germano (2010) developed the Remittance Index comprised of three components: the amount, the regularity and the duration of remittances received. The index thus captures "the extent to which remittances are a substantial, reliable, and enduring source of income to the household" (Germano 2010, 153). The LiK survey allows us to capture both the amount and regularity of remittances across all waves. Specifically, we rely on respondents' answers to the following questions: 'How much money did household migrants send over the last 12 months?' for the amount, and 'Did you 
receive the money sent by migrants always at the same point of time (is the receiving of money regular)?' for regularity. Regarding the amount of remittances, we recoded the amount received (in Som) into three categories: 1) those that received amounts ranging between the minimum and mean value in the respective survey wave, 2) those that received amounts between the mean and one standard deviation above the mean value in the respective survey wave, and 3) those that received amounts larger than one standard deviation above the mean value in the respective survey wave. Regarding the regularity of remittances, respondents could choose between the following answer categories: '1) yes, 2) no or 3) different (varies)'. We recoded the answer in the following way: 1) no, 2) different and 3) yes. In keeping with Germano (2010), we added both measures to a Remittance Index that takes on a minimum value of 1) and a maximum value of 6) (for more information on the construction of the Remittance Index see Table A.5 of the SI). We constructed the variable Change in Remittance Index ${ }_{t-(t-1)}$ that subtracts the value of the index in wave t-1 from the value of the index in wave $t$ for each respondent. The variable Change in Remittance Index $t_{-}$ (t-1) ranges from a minimum value of -5 to a maximum value of 5 .

In addition, we construct a dichotomous measure of declines in remitted income, Reduction in Remittances. This variable takes on a value of 1) when respondents experienced a reduction in the amount and/or frequency of remitted income, and 0) if they did not. This dichotomous measure allows us to compare the effect of experiencing a reduction in remittances to other household income shocks that respondents were asked about in the Kyrgyz survey, and to check the robustness of our results against matching analyses.

Our main dependent variable asks respondents how much they generally trust the president. Relying on this item, we construct a variable, presidential trust, which ranges from 1) to 4), with higher values denoting greater trust in the president. In line with other work, we use trust in the incumbent, here the president, as a proxy of incumbent approval (e.g. 
Williams 1985, Ahmed 2017). ${ }^{5}$ Based on this measure we construct a variable Change in Trust in the President $t_{\mathrm{t}-(\mathrm{t}-1)}$ by subtracting the trust in the president at wave $\mathrm{t}-1$ from trust in the president at wave $t$. This variable ranges from a minimum value of -3) and a maximum value of 3). Overall, we expect to find a positive effect for a change in the amount and the frequency of remittances received or in the Remittance Index, and a negative effect for reductions in remittances on change in trust in the president.

The analyses also include a set of control variables, including gender, age, education, marital status, ethnicity, intention to migrate, life satisfaction and attitude to risk. Controlling for ethnicity in the context of Kyrgyzstan is important as ethnicity captures one of the most salient political divides in the country. It serves somewhat as a proxy for partisanship in a context with a traditionally weak party system, and where ethnic and clan divisions are very important (Fumagalli 2016). We also control for other sources of income or wealth, such as being in paid employment, household income and a wealth index. Summary statistics of all variables used in the analysis of the LiK data and question wordings are provided in Tables

\section{A.2-A.3 of the SI.}

Our dataset pools observations for respondents nested in households across the four different waves. To deal with both the temporal and nested data, we employ two different estimation strategies. First, we perform a panel data generalized least squares (GLS) estimation with household and panel wave fixed effects as well as random effects varying across individuals. Second, we use a hierarchical linear model (HLM) to deal with the fact that individuals are nested in households and waves (Snijders and Bosker 2012). We estimate a model consisting of two levels, one is the respondent level and the other is a

\footnotetext{
${ }^{5}$ In the LiTS II survey of 2010, measures of trust are highly correlated with evaluations of government performance. The bivariate correlation between government approval and trust in the national government is 0.5 , statistically significant at the 0.001 level.
} 
household*wave level. The HLM results are reported in Tables C.4, C.8 and C.11 in the SI. In both estimations, we regress changes in trust in the president on changes in remittances. To check the robustness of our results, we also employ nearest neighbor matching (NN matching) based on our dichotomous measure of a decline in remittances. These results are reported in Tables C.6, C.7, C.10, C.13 and C.14 of the SI, and show that the effect of remittances remain robust even when we match respondents on a series of covariates that could predict their susceptibility to experiencing a decline in remittances in the first place.

\section{Results}

Models 1 through 3 in Table 2 explore the relationship between changes in remittances and changes in incumbent support. The dependent variable in Models 1 and 3 is the difference in levels of trust in the President across survey waves, while our measure of changes in remittances differs across models. Model 1 shows the results for changes in the amount of remitted income, Model 2 the results for changes in the frequency with which respondents receive remittances, and Model 3 the results for changes in our index. All results are based on a panel data model that accounts for repeated observations of individuals and includes both household and survey wave fixed effects. The results show that an increase in remittances coincides with an increase in trust in the president, while a decrease in remittances decreases trust in the president. For example, when a respondent experiences a change in remitted income from the minimum to maximum amount, trust in the president increases by 2.8 points on a six-point scale. These results are robust against different ways to measure changes in remitted income, different estimation methods and different model specifications (see Tables C.4-C.7 in the SI). 
Table 2: Changes in remittances and changes in trust in the president, Kyrgyzstan panel data

\begin{tabular}{|c|c|c|c|}
\hline \multirow[b]{2}{*}{ COVARIATES } & \multicolumn{3}{|c|}{ Change in Trust in President $t-(t-1)$} \\
\hline & Model (1) & Model (2) & Model (3) \\
\hline Change in Amount of & $0.048^{* *}$ & \multirow{6}{*}{$\begin{array}{c}0.070 * * \\
(0.032)\end{array}$} & \\
\hline Remittances $_{\mathrm{t}-(\mathrm{t}-1)}$ & $(0.019)$ & & \\
\hline Change in Frequency of & & & \\
\hline Remittances $_{\mathrm{t}-\mathrm{t}-\mathrm{t})}$ & & & \\
\hline Change in Remittances & & & $0.064 * * *$ \\
\hline Index $_{t-(t-1)}$ & & & $(0.023)$ \\
\hline \multirow[t]{2}{*}{ Primary Education } & 0.252 & 0.294 & 0.242 \\
\hline & $(0.412)$ & $(0.411)$ & $(0.412)$ \\
\hline \multirow[t]{2}{*}{ Secondary Education } & 0.421 & 0.433 & 0.423 \\
\hline & $(0.397)$ & $(0.396)$ & $(0.397)$ \\
\hline \multirow[t]{2}{*}{ University Education } & 0.512 & 0.524 & 0.524 \\
\hline & $(0.432)$ & $(0.430)$ & $(0.432)$ \\
\hline \multirow[t]{2}{*}{ Gender } & -0.031 & -0.026 & -0.031 \\
\hline & $(0.074)$ & $(0.074)$ & $(0.074)$ \\
\hline \multirow{2}{*}{ Age } & $0.008 * * *$ & $0.008 * * *$ & $0.008 * * *$ \\
\hline & $(0.003)$ & $(0.003)$ & $(0.003)$ \\
\hline \multirow[t]{2}{*}{ Married } & -0.042 & -0.075 & -0.060 \\
\hline & $(0.110)$ & $(0.110)$ & $(0.110)$ \\
\hline \multirow[t]{2}{*}{ Ethnicity } & 0.121 & 0.142 & 0.147 \\
\hline & $(0.502)$ & $(0.500)$ & $(0.502)$ \\
\hline \multirow[t]{2}{*}{ Employed } & -0.014 & -0.058 & -0.032 \\
\hline & $(0.111)$ & $(0.111)$ & $(0.110)$ \\
\hline \multirow{2}{*}{ Intention to Migrate } & -0.047 & -0.078 & -0.085 \\
\hline & $(0.174)$ & $(0.173)$ & $(0.174)$ \\
\hline \multirow[t]{2}{*}{ Wealth Index } & -0.014 & -0.009 & -0.012 \\
\hline & $(0.018)$ & $(0.018)$ & $(0.018)$ \\
\hline \multirow[t]{2}{*}{ Household Income } & $-0.001 * *$ & -0.001 & $-0.0005^{*}$ \\
\hline & $(0.0003)$ & $(0.000)$ & $(0.0003)$ \\
\hline \multirow[t]{2}{*}{ Life Satisfaction } & $0.070 * * *$ & $0.064 * *$ & $0.069 * * *$ \\
\hline & $(0.024)$ & $(0.025)$ & $(0.024)$ \\
\hline \multirow[t]{2}{*}{ Risk Attitude } & 0.023 & 0.019 & 0.026 \\
\hline & $(0.018)$ & $(0.018)$ & $(0.018)$ \\
\hline \multirow[t]{2}{*}{ Constant } & 0.274 & 0.218 & 0.247 \\
\hline & $(1.065)$ & $(1.060)$ & $(1.063)$ \\
\hline \multicolumn{4}{|l|}{ Fixed Effects } \\
\hline Household & $\checkmark$ & $\checkmark$ & $\checkmark$ \\
\hline Survey Wave & $\checkmark$ & $\checkmark$ & $\checkmark$ \\
\hline Observations (Individuals, & 1,287 & 1,273 & 1,287 \\
\hline Groups) & 866 & 864 & 866 \\
\hline $\mathrm{R}^{2}$ Between & 0.59 & 0.58 & 0.59 \\
\hline
\end{tabular}

Notes: Models 1 through 3 present regression coefficients with standard errors in parentheses based on a panel GLS estimation with random effects varying across individuals and household and wave fixed effects. Being illiterate is the reference category for education. For robustness check, see Tables C.4-C.7 of the SI. Significant at the ${ }^{* * *} \mathrm{p} \leq 0.01,{ }^{* *} \mathrm{p} \leq 0.05,{ }^{*} \mathrm{p} \leq 0.10$ level. Source: Life in Kyrgyzstan Panel Survey, 2010-2013. 
Still we might be concerned that changes in the Kyrgyz economy could be driving both the changes in remittances and incumbent approval. To deal with this concern, we employ an instrumental variables (IV) regression. As an instrument, we use annual change in unemployment in Russia, the major destination country for Kyrgyz migrants, interacted with (or weighted by) the share of women in each household. The share of female household members is a key household level characteristic correlated with the receipt and amount of remittances, but not with incumbent approval. The instrument we employ incorporates the idea, common in previous studies, that growth in the migrant host country is likely to be a key driver of remittances (e.g. Barajas et al. 2009; Singer, 2012). The results, which are reported in Table D.1 of the SI, show that remittance effects on approval remain robust, even when we instrument remittance amounts using annual changes in unemployment in Russia weighted by the share of women in the household.

Before turning to the analysis of the mechanism driving the connection between changes in remittances and approval, we investigate how a decline in remittances stacks up against other shocks that individuals face. We do so by comparing the effect of experiencing a reduction in remittances on incumbent approval against the effects of other adverse income shocks that individuals may experience, such as the effect of having suffered a loss in agricultural income or being affected by landslides. Respondents in the LiK surveys were asked if they had suffered agricultural loss, for example through diseases in crop or livestock, or were affected by a landslide. The variables Reduction in Remittances, Agricultural Loss and Affected by Landslides take on a value of 1) when respondents experienced this kind of shock and a value of 0 ) if not. While 28.2 per cent of respondents who received remittances across the four waves stated that they had experienced a decline in remittances, 12.7 per cent reported that they lost income due to agricultural loss, and 11.6 per cent were adversely affected by landslides. We regress changes in trust in the president on these household 
income shocks, while controlling for the full set of covariates introduced in Table 2. Full results are reported in Table B.2 in the SI. Figure 3 graphically displays the size of the effects. Importantly, the figure shows that the effect of a reduction in remittances is of similar size to the effect of a landslide or agricultural loss. This underscores the importance of reductions in remittances for incumbent approval.

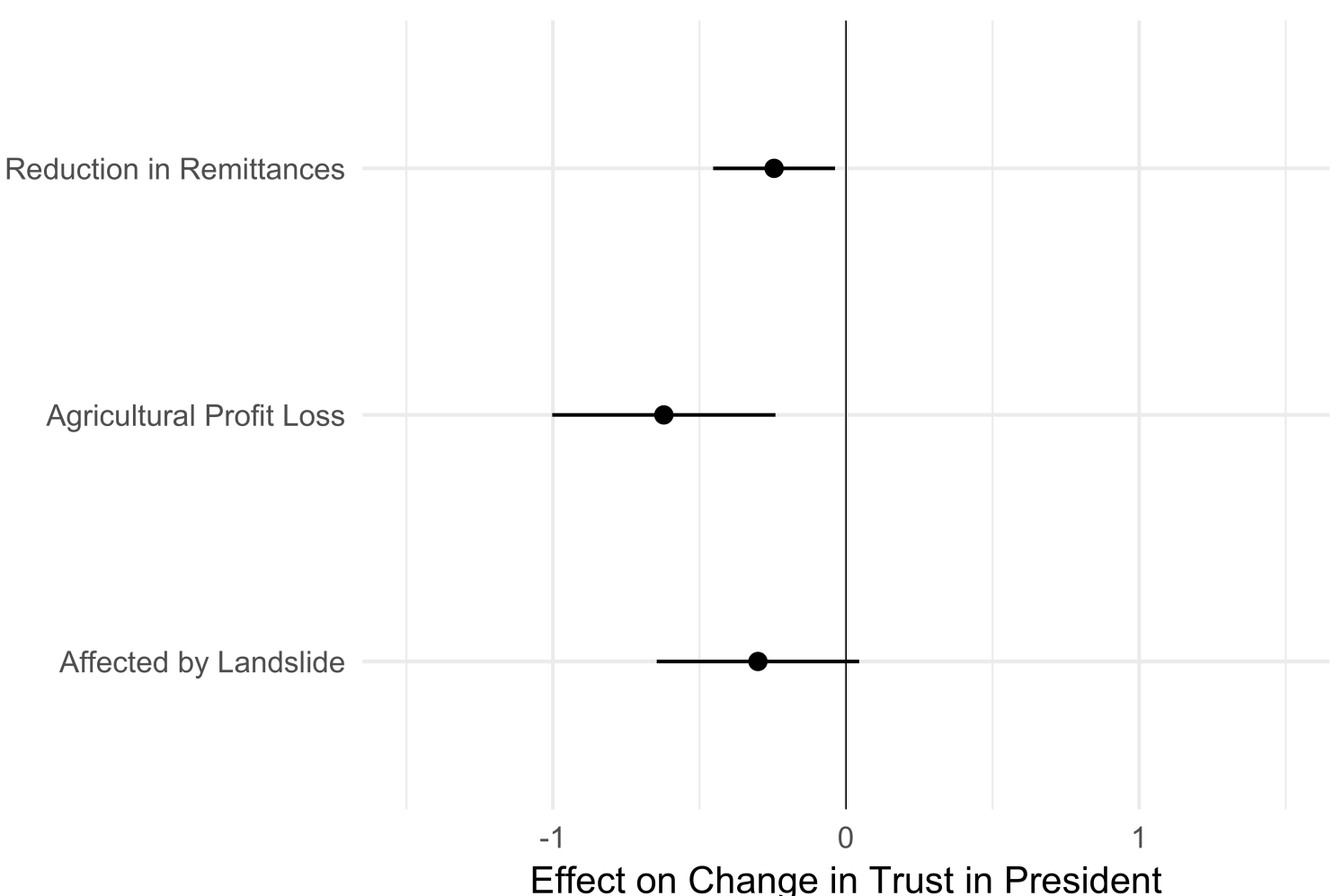

Notes: The figure presents regression coefficients and 95 per cent confidence intervals based on a panel GLS estimation with random effects varying across individuals and household and wave fixed effects. Full results are reported in Table B.2 of the SI and robustness checks in Tables C.8-C.10. Source: Life in Kyrgyzstan Panel Survey, 2010-2013.

Figure 3: The effect of household shocks on trust in the president

Our argument suggests that recipients who experience a decline in remittances become less satisfied with their economic situation, thereby undermining their support for the incumbent. Conversely, when remittances increase, the economic evaluations of recipients will improve, resulting in more support for the incumbent. To test this mechanism with LiK data, we rely on respondents' answers to the following question 'When you think about your own 
economic situation, how worried are you about it?' The answer categories vary from 0 ) 'not worried at all' to 10) 'extremely worried.' We capture changes in concerns about their personal economic situation by subtracting their answers in wave t-1 from their answers in wave $\mathrm{t}$ for each respondent.

Table 3 presents the results of regressing changes in concern about one's own economic situation on changes in remittances, using our three different measures of fluctuations and a panel data model that accounts for repeated observations of individuals and includes both household and survey wave fixed effects. The results suggest that respondents who experienced an increase in the amount of remitted income (Model 1), the frequency with which they receive remittances (Model 2) or in the Remittance Index (Model 3) are indeed less worried about their own economic situation. When a respondent experiences a change in remitted income from the minimum to maximum amount, concern about her own economic situation decreases by 9.55 points on a twenty-point scale. These effects are robust across different estimation methods and model specifications (see Tables C.11-C.13 of the SI). 
Table 3: Changes in remittances and concern about personal economic situation, Kyrgyzstan panel data

\begin{tabular}{|c|c|c|c|}
\hline & \multicolumn{3}{|c|}{ Change in Concern about Personal Economic Situation t-(t-1) } \\
\hline & \multicolumn{2}{|c|}{ Model (1) Model (2) } & \multirow[t]{3}{*}{ Model (3) } \\
\hline Change in Amount of & $-0.162 * * *$ & \multirow{6}{*}{$\begin{array}{c}-0.245^{* * *} \\
(0.077)\end{array}$} & \\
\hline Remittances $_{\mathrm{t}-(\mathrm{t}-1)}$ & $(0.045)$ & & \\
\hline Change in Frequency of & & & \\
\hline Remittances $_{\mathrm{t}-(\mathrm{t}-1)}$ & & & \\
\hline Change in Remittances & & & $-0.141 * *$ \\
\hline Index $_{\mathrm{t}-(\mathrm{t}-1)}$ & & & $(0.055)$ \\
\hline \multirow[t]{2}{*}{ Primary Education } & 0.724 & 0.731 & 0.728 \\
\hline & $(0.985)$ & $(0.982)$ & $(0.988)$ \\
\hline \multirow[t]{2}{*}{ Secondary Education } & 0.444 & 0.454 & 0.423 \\
\hline & $(0.953)$ & $(0.949)$ & $(0.956)$ \\
\hline \multirow[t]{2}{*}{ University Education } & -0.028 & -0.030 & -0.098 \\
\hline & $(1.035)$ & $(1.032)$ & $(1.038)$ \\
\hline \multirow[t]{2}{*}{ Gender } & 0.033 & 0.037 & 0.034 \\
\hline & $(0.176)$ & $(0.177)$ & $(0.177)$ \\
\hline \multirow[t]{2}{*}{ Age } & -0.001 & -0.001 & -0.009 \\
\hline & $(0.007)$ & $(0.001)$ & $(0.007)$ \\
\hline \multirow[t]{2}{*}{ Married } & 0.174 & 0.277 & 0.223 \\
\hline & $(0.262)$ & $(0.262)$ & $(0.263)$ \\
\hline \multirow[t]{2}{*}{ Ethnicity } & -0.155 & -0.231 & -0.203 \\
\hline & (1.203) & (1.198) & $(1.207)$ \\
\hline \multirow[t]{2}{*}{ Employed } & 0.292 & 0.357 & 0.343 \\
\hline & $(0.264)$ & $(0.266)$ & $(0.265)$ \\
\hline \multirow[t]{2}{*}{ Intention to Migrate } & -0.762 & -0.654 & -0.669 \\
\hline & $(0.415)$ & $(0.413)$ & $(0.416)$ \\
\hline \multirow[t]{2}{*}{ Wealth Index } & 0.052 & 0.018 & 0.044 \\
\hline & $(0.043)$ & $(0.043)$ & $(0.043)$ \\
\hline \multirow[t]{2}{*}{ Household Income } & -0.0004 & -0.001 & -0.001 \\
\hline & $(0.001)$ & $(0.001)$ & $(0.001)$ \\
\hline \multirow[t]{2}{*}{ Life Satisfaction } & -0.053 & -0.037 & -0.040 \\
\hline & $(0.059)$ & $(0.059)$ & $(0.059)$ \\
\hline \multirow[t]{2}{*}{ Risk Attitude } & 0.027 & 0.024 & 0.020 \\
\hline & $(0.044)$ & $(0.044)$ & $(0.044)$ \\
\hline \multirow[t]{2}{*}{ Constant } & -3.146 & -2.776 & -3.060 \\
\hline & $(2.553)$ & (2.544) & $(2.561)$ \\
\hline \multicolumn{4}{|l|}{ Fixed Effects } \\
\hline Household & $\checkmark$ & $\checkmark$ & $\checkmark$ \\
\hline Survey Wave & $\checkmark$ & $\checkmark$ & $\checkmark$ \\
\hline Observations (Individuals & 1,297 & 1,283 & 1,297 \\
\hline Groups) & 877 & 875 & 877 \\
\hline $\mathrm{R}^{2}$ Between & 0.65 & 0.64 & 0.64 \\
\hline
\end{tabular}

Notes: Models 1 through 3 present regression coefficients with standard errors in parentheses based on a panel GLS estimation with random effects varying across individuals and household and wave fixed effects. Being illiterate is the reference category for education. For robustness check, see Tables C.11-C.13 of the SI. Significant at the ${ }^{* * *} \mathrm{p} \leq 0.01,{ }^{* *} \mathrm{p} \leq 0.05,{ }^{*} \mathrm{p} \leq 0.10$ level. Source: Life in Kyrgyzstan Panel Survey, 2010-2013. 


\section{Cross sectional survey data}

To bolster the external validity of the findings from Kyrgyzstan and probe the mechanism further, we turn to the 2010 LiTS survey, which includes data from 28 countries in Central Eastern Europe, the Caucasus and Central Asia. Respondents were asked if they were adversely financially affected since the crisis ('over the last two years'), and what the source was: a) 'head of household lost job', b) 'other household member lost job', c) 'family business closed', d) 'working hours reduced', e) 'wages delayed/suspended', f) 'wages reduced', g) 'reduced flow of remittances', h) 'family member returned home from abroad' or i) 'other'. We are interested in those who report experiencing a reduced flow in remittances, and construct a variable, Reduction in Remittances, which is coded as 1) if respondents state that they experienced a decline in remittances and 0) if they experienced another economic household shock:

In order to examine the effect of a decline in remitted income on approval, we rely on an item asking respondents 'to rate the overall performance of the national government' from 1) 'very bad' to 5) 'very good'. To test our misattribution argument, we also examine if those who experienced a decline in remitted income are also more likely to blame the incumbent for the crisis compared to those who experienced a shock due to other sources, such as a job loss or wage reduction. This is arguably a conservative test of our argument as we are only examining those who have experienced an economic household shock and comparing those for whom the shock was due to a decrease in remitted income originating from outside the country to those for whom the shock in income was based on a change stemming from the national economy. At the individual level, we control for other sources of income or wealth, such as being in paid employment and house ownership, as well as age and education. At the country level, we control for macro-economic performance using a growth indicator. Descriptive statistics are provided in Table A.6 of the SI. 
Because of the natural hierarchies in the data (individuals who are nested in countries), we employ a HLM regression analysis. Table 4 reports the results. The analysis presented in Model 1 suggests that evaluations of government performance are lower among respondents who experienced a decline in remittances, compared to those otherwise affected by the recession. Results reported in Model 2 suggest that holding all covariates at their means, respondents who experience a decline in remittances are, by approximately 8 per cent, more likely than respondents otherwise affected by the Great Recession to blame the national government for the downturn. Conversely, respondents with access to a more robust portfolio of assets are less likely to blame the national government for the crisis. The marginal effect of the wealth index on blame attributions is around 7 per cent. Lastly, the growth indicator also behaves in the anticipated way. Evaluations of incumbent performance are higher in countries with higher growth, while blame attribution is lower. Overall, the evidence presented in Table 4 corroborates our results from the Kyrgyz sample. People who experience a reduction in remitted income are less likely to be satisfied with the government's record and more likely to blame the government for a deterioration of economic conditions. Altogether, the evidence suggests remittances can drive fluctuations in incumbent approval in recipient countries. 
Table 4: A reduction in remittances on government approval and economic blame attribution

\begin{tabular}{|c|c|c|}
\hline & $\begin{array}{c}\text { Government } \\
\text { Approval } \\
\text { Model (1) }\end{array}$ & $\begin{array}{c}\text { Economic Blame } \\
\text { Attribution } \\
\text { Model (2) }\end{array}$ \\
\hline Reduction in Remittances & $\begin{array}{c}-0.038 * * \\
(0.018)\end{array}$ & $\begin{array}{l}0.079 * \\
(0.043)\end{array}$ \\
\hline Age & $\begin{array}{c}0.001 * * * \\
(0.0005)\end{array}$ & $\begin{array}{c}-0.003 * * * \\
(0.001)\end{array}$ \\
\hline Gender & $\begin{array}{c}-0.069 * * * \\
(0.014)\end{array}$ & $\begin{array}{l}-0.043 \\
(0.032)\end{array}$ \\
\hline Married & $\begin{array}{l}-0.008 \\
(0.014)\end{array}$ & $\begin{array}{c}0.095 * * * \\
(0.033)\end{array}$ \\
\hline Employed & $\begin{array}{l}0.027^{*} \\
(0.015)\end{array}$ & $\begin{array}{l}-0.026 \\
(0.035)\end{array}$ \\
\hline Wealth Index & $\begin{array}{l}-0.004 \\
(0.004)\end{array}$ & $\begin{array}{c}-0.073 * * * \\
(0.010)\end{array}$ \\
\hline Education & $\begin{array}{l}-0.011 \\
(0.012)\end{array}$ & $\begin{array}{l}-0.048^{*} \\
(0.027)\end{array}$ \\
\hline Life Satisfaction & $\begin{array}{c}0.165 * * * \\
(0.007)\end{array}$ & $\begin{array}{c}-0.141 * * * \\
(0.015)\end{array}$ \\
\hline Risk Attitude & $\begin{array}{l}-0.001 \\
(0.003)\end{array}$ & $\begin{array}{l}-0.003 \\
(0.007)\end{array}$ \\
\hline Annual Growth & $\begin{array}{c}0.101 * * * \\
(0.021)\end{array}$ & $\begin{array}{c}-0.122 * * * \\
(0.041)\end{array}$ \\
\hline Constant & $\begin{array}{c}2.008^{* * *} \\
(0.096)\end{array}$ & $\begin{array}{c}0.798 * * * \\
(0.197)\end{array}$ \\
\hline Log Likelihood & -22444 & -12323 \\
\hline AIC & 44914.45 & 24670.72 \\
\hline $\mathrm{BIC}$ & 45015.38 & 24765.37 \\
\hline $\begin{array}{l}\text { Individuals } \\
\text { Countries }\end{array}$ & $\begin{array}{c}17,389 \\
28\end{array}$ & $\begin{array}{c}19,684 \\
28\end{array}$ \\
\hline
\end{tabular}

Notes: Table entries are HLM regression coefficients with standard errors in parentheses for model 1 and HLM logistic regression coefficients with standard errors in parentheses for model 2. In both models individuals are nested in countries. For robustness checks see Table C.15 in the SI. Significant at the $* * * p \leq 0.01, * * p \leq 0.05$, * $\mathrm{p} \leq 0.10$ level. Source: Life in Transition Survey, 2010.

\section{Evaluating the Mechanism}

In the previous sections, we have theoretically argued and empirically demonstrated that changes in remittances drive fluctuations in economic assessments and evaluations of the incumbent. We have also suggested that this relationship can be understood as a form of misattribution, in the sense that voters are rewarding or punishing incumbents for economic developments originating from elsewhere. While this behavior is rational, particularly in a 
context where economic performance is largely driven by exogenous shocks, it has implications for the economic vote as an instrument of accountability (e.g. Campello and Zucco 2017).

There may be another mechanism at work here however, where households update their evaluations of incumbent competence, because they think the incumbent facilitates, or hinders remittance transfers. If that were the case, we would expect that fluctuations in remittances should exclusively influence support for the president, or central government authorities. Yet, as we show in Table D.2 in the SI, fluctuations in remittances also influence support for local community leaders. Arguably, it is unlikely that local community leaders could manipulate remittance inflows, or that voters would expect them to, as they lack the authority to manipulate the official exchange rate or to introduce schemes to encourage migrants to remit more.

In a similar vein, one could argue that households affected by a decline in remittances are holding incumbents accountable for either failing to prevent declines in remittances, and/or for failing to 'treat' the welfare consequences of the decline. As Ashworth, Bueno de Mesquita and Friedenberg (2018) have argued, even exogenous shocks provide an opportunity for voters to learn new information about an incumbent. Here the change in remittances would be such a shock, and the ability of the government to respond to this shock or their preparedness to compensate its consequences could give voters new information about the incumbent (e.g. Acevedo 2016). As such, voters who experience a decline in remittances may disapprove of the incumbent not because of a mechanism underpinned by misattribution, but one rooted in an increased need for national public services. If this were the case, voters could be punishing governments for their response to the exogenous shock, rather than for the decline in remittances. This is what we call the treatment responsibility mechanism (Javeline 2003). 
Can we separate out these different mechanisms from our results? Although given the observational nature of our data we cannot be definitive, based on three points that we discuss below, we believe that the weight of evidence is more strongly in line with the misattribution mechanism. To begin with, in our analysis of changes in incumbent approval, we relied on a continuous measure of changes in remittances (see Table 2). The evidence suggested that while decreases in remittances coincided with a decline in trust in the president, increases in remittances led to an increase in trust in the president. While it would make sense that recipients would punish governments for a lack of preparedness when remittances decline, rewarding governments when remittances increase is probably not suggestive of this mechanism. It is not clear what recipients would be rewarding the government for post facto, or how this would translate into new information. Unlike the situation with a sharp decline in remittances, which could be considered an exogenous shock, and recipients can infer new information from the degree of government preparedness because they actively seek something from the government, in the case of increases in remittances, recipients are not seeking compensation from the government and hence the extent of government preparedness will remain unobserved. As such, evidence that fluctuations in remittances ameliorate trust would seem to be an example of misattribution.

Second, we find little empirical support for the argument that households that experience a decline in remittances become less satisfied with public safety nets, in the form of welfare provision or public goods. When remittances decline, as Acevedo (2016) has suggested, recipients may actually increase their demand for public safety nets and if the quality of public services disappoint, a recipient who experiences a reduction in remittances might sanction an incumbent to a greater degree than someone who has not experienced such a decline. In the 2013 wave of the LiK survey, respondents were asked how satisfied they are with the public services in the country. The answer categories ranged from 1) 'very 
dissatisfied' to 4) 'very satisfied'. We regressed people's satisfaction with public service provision on our three different measures of changes in remittances, and the results are presented in Table D.3 in the SI (for robustness checks see Table D.4). We find no relationship between changes in remitted income and satisfaction with public service provision.

The existence of Hometown Associations (HTAs), organizations that allow migrants from the same region to financially support development projects in their city or region of origin and which are very common in the Americas, would actually bias the results of our regressions downward, given their primary activity of supporting local health and education projects (Orozco and Rouse 2013). In general however, such groups are not active in Kyrgyzstan or in our larger sample. ${ }^{6}$ Moreover, analysis relying on evidence from the LiTS surveys suggests that satisfaction with welfare provisions does not moderate attributions of responsibility for declines in remittances (see Table D.5 in the SI).

Next, we examine whether political information, which is crucial for blame attribution (e.g. Gomez and Wilson 2001; De Vries and Giger 2014), moderates the relationship between remittances and support for the president. Based on the treatment responsibility mechanism, one would expect those who are most informed to be most likely to sanction the incumbent. Those who are more informed are more likely to have developed some pre-shock evaluation of the government. As a result, they are also more likely to be able to use the information from the incumbent's response to an exogenous shock to update their post-shock assessment of this incumbent. The opposite should hold for the misattribution mechanism. People with more political information should be better able to identify the merits of incumbent performance and thus reward or punish the incumbent less for changes in remittances.

\footnotetext{
${ }^{6}$ Of the 28 countries in the 2010 LiTS Survey, only Moldova and Albania appear to have active HTAs.
} 
Although in a volatile economic environment like Kyrgyzstan, the competency signal is small, and it may still be rational to hold the incumbent to account for economic performance driven by exogenous events, those who are more informed are less likely to do so because they realize that the incumbent is not responsible for changes in remitted income.

We examine these expectations by regressing changes in trust in the president on changes in the amount of remitted income received, as we do in Table 2, but interact the changes in the amount of remitted income with people's access to political information. We capture access to political information by relying on a set of questions asking respondents if they consult different news sources, such as radio, TV or the internet, or rely on family or friends to learn about the situation in their community, Kyrgyzstan or the world. We create an additive scale ranging from 1) to 4), where 1) indicates that they use none or only one of these sources and 4) indicates that they rely on four or more. Figure 4 shows the marginal effect of changes in the amount of remitted income for people at different levels of political information (full results are presented in Table B.3 and robustness checks in Table C.16 and Figure C.1 in the SI). The results suggest that attribution of responsibility for changes in remittances is declining as political sophistication increases. These findings are largely in line with the misattribution mechanism. 


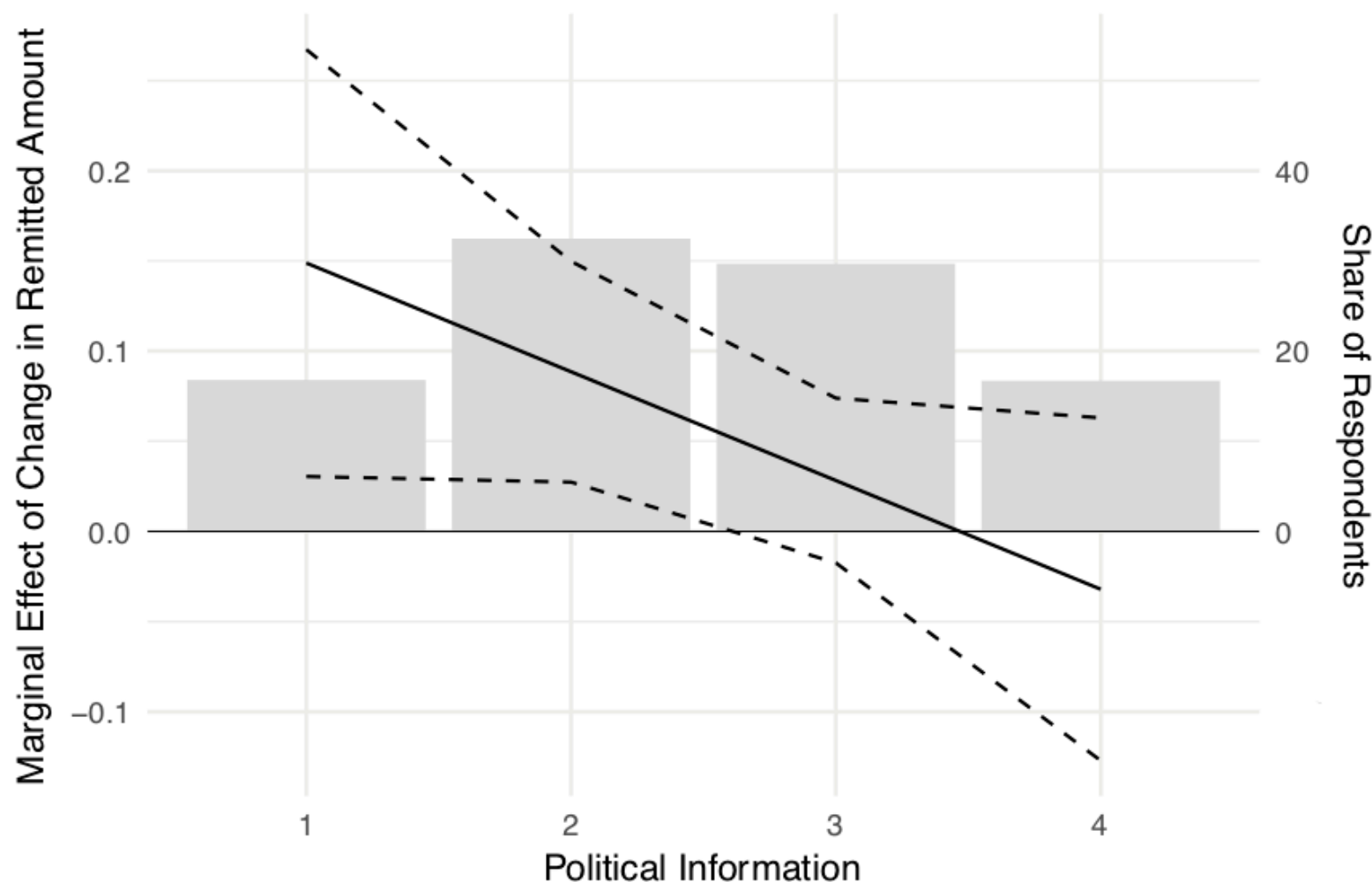

Notes: The figure presents the marginal effect of changes in the amount of remittances on changes in trust in the president at different levels of access to political information with 95 per cent confidence intervals based on a panel GLS estimation with random effects varying across individuals and household and wave fixed effects. For full results see Table B.3 and for robustness checks see Table C.15 and Figure C.1 in the SI. Source: Life in Kyrgyzstan Panel Survey, 2010-2013.

Figure 4: The effect on changes in remittances on changes in trust in the president by access to political information

\section{Conclusion}

Remittances are now one of the largest flows of capital to developing world economies, in some cases, outstripping FDI, portfolio capital and overseas development assistance and for many households, they represent a crucial economic lifeline. In this study, we contribute to an emerging literature concerned with the effect of remittances on individual political attitudes and political behavior (Meseguer et al. 2016; Germano 2013; Bravo 2012; Ahmed 2017). Taking our cue from recent work on the relationship between remittances and the economic vote (Germano 2010; Bravo 2012) and on misattribution and economic voting in the developing world (Campello and Zucco 2016), we argued that when remittances change, 
recipients will attribute the change in their economic situation to the incumbent. We are able to identify this mechanism by modeling changes in remittances on changes in economic evaluations and support for the incumbent using a unique four-wave panel study of Kyrgyz citizens between 2010-2013. We supplemented this data with cross-national survey evidence from 28 countries from 2010.

We believe that our findings are important for a number of different bodies of work. First, we know little about the political effects of remittances. While there is a growing literature on the effect of remittances on public policy at the macro level (e.g. Abdih et al. 2012; Tyburski 2012; Aparicio and Meseguer 2012; Singer 2012; Pfutze 2014; O’Mahony 2013; Ahmed 2012; Escribà-Folch et al. 2015; Leblang 2017), only a handful of studies have examined how the receipt of remittances might condition the economic vote at the individual level (Bravo 2012; Germano 2012; Ahmed 2017). So far, no work has explored the dynamics of remittances. Our study is the first study to explore how changes in remittances at the individual level might affect changes in incumbent support.

Second, our findings suggest that while the receipt of remittances does indeed bolster support for the incumbent all else equal as existing work suggests, this works to the incumbent's disadvantage when remittances decline. Remittances are not a constant and they generate dynamic attitudes and political behavior in response to their own dynamism. Our findings may account for some of the conflicting evidence in the literature thus far. Some empirical work suggests that remittances can prolong the stability of authoritarian regimes (Ahmed 2012) while other work shows that they might hinder longevity (Escribà-Folch et al. 2015). This study suggests that in order to better understand the relationship between remittances and regime longevity it is crucial to consider fluctuations in the volume and frequency of remittances. 
Our ability to model these types of changes in remittance flows, thanks to the fourwave panel study from Kyrgyzstan, will also be relevant for work on competence models in economic voting (e.g. Stigler 1973; Duch and Stevenson 2008; Campello and Zucco 2016). This work has focused on ascertaining in what contexts voters might be able to parse out the difference between economic outcomes driven by the competence of their leaders, compared to economic outcomes driven by exogenous global forces. One of the big issues facing this work has been the identification of misattribution effects (Campello and Zucco 2016). Remittances, given they are largely a private fiscal transfer shaped by economic conditions elsewhere, are a particularly neat way to test misattribution. Although exogenous shocks may be the only source of information about incumbent competence for rational voters in volatile contexts, the type of misattribution we examine here will still have implications for the economic vote as a mechanism of accountability and as such, it will have important normative ramifications.

From a more general perspective, we think this point highlights the precarious equilibrium that remittances can generate. When evaluations of the government at home respond to fluctuations in remitted income, largely driven by events and developments abroad, accountability mechanisms, which are rudimentary in many remittance-dependent economies could erode even further. When countercyclical (Yang and Choi 2007), remittances could bolster trust in incumbents even when economic performance at home is poor. They may also encourage governments to reduce social safety nets and increase patronage (Ahmed 2012). On the other hand, declines in remittances, and related economic grievances among recipients, may result in greater electoral punishment for events incumbents do not fully control.

There are still some puzzles to unravel. We still need to explore how changes in remittances might channel egocentric and sociotropic evaluations in different ways and what 
this might mean for incumbent support. We were constrained by our data in this respect. We also need to further explore the mechanisms underlying the political consequences of fluctuations in remittances. Based on the observational data at our disposal here, the empirical evidence seems largely suggestive of a misattribution mechanism. Nonetheless, we think a fruitful avenue of future research would be to try to disentangle the difference between the misattribution and treatment responsibility mechanisms through carefully designed experiments. These remain important avenues for future work. 


\section{References}

Abdih, Yasser, Ralph Chami, Jihad Dagher, and Peter Montiel. 2012. "Remittances and Institutions: Are Remittances a Curse?" World Development 40 (4): 657-666.

Acevedo, Jesse. 2016. Move, Work, Save, Send: The Political Economy of Migration and Remittances. PhD dissertation, Department of Political Science, University of California, Los Angeles.

Ahmed, Faisal Z. 2012. "The Perils of Unearned Foreign Income: Aid, Remittances, and Government Survival.” American Political Science Review 106 (1): 146-165.

Ahmed Faisal Z. 2017. "Remittances and Incumbency: Theory and Evidence." Economics \& Politics 29 (1): 22-47.

Aparicio, Francisco Javier, and Covadonga Meseguer. 2012. "Collective Remittances and the State: The $3 \times 1$ Program in Mexican Municipalities." World Development 40 (1): 206-222.

Ashworth, Scott, Ethan Bueno de Mesquita, and Amanda Friedenberg. 2018. "Learning about Voter Rationality." American Journal of Political Science 62 (1): 37-54.

Barajas, Adolfo, Ralph Chami, Connel Fullenkamp, Michael Gapen, and Peter J. Montiel. 2009. "Do Workers' Remittances Promote Economic Growth?" IMF Working Papers 09/153:1-22.

Bravo, Jorge. 2012. "Credit where Credit is Due? Remittances, Economic Assessments, and Presidential Approval in Latin America." Working Paper, Niehaus Center for Globalization and Governance, Princeton University.

Brück, Tilman, Damir Esenaliev, Antje Kroeger, Alma Kudebayeva, Bakhrom Mirkasimov, and Susan Steiner. 2014. "Household Survey Data for Research on Well-Being and Behavior in Central Asia." Journal of Comparative Economics 42 (3): 819-35.

Campello, Daniella and Zucco Jr, Cesar. 2016. "Presidential Success and the World Economy." The Journal of Politics 78 (2): 589-602.

Campello, Daniella and Zucco Jr, Cesar. 2017. "Rewarding Merit or Luck? The Competency Signal in Comparative Perspective." Paper presented at the American Political Science Annual Conference, San Francisco, August 31 - September 3.

Chaudhry, Kiren Aziz. 1997. The Price of Wealth: Economies and Institutions in the Middle East. Ithaca: Cornell University Press.

Córdova, Abby, and Jonathan Hiskey. 2015. "Shaping Politics at Home: Cross-Border Social Ties and Local-Level Political Engagement." Comparative Political Studies 48 (11): 1454-1487.

Cornelius, Wayne A., and Marc R. Rosenblum. 2005. "Immigration and Politics." Annual Review of Political Science, 8: 99-119.

De Vries, Catherine E., and Nathalie Giger. 2014. "Holding Governments Accountable? Individual Heterogeneity in Performance Voting." European Journal of Political Research 53 (2): 345-362.

Downs, Anthony. 1957. "An Economic Theory of Political Action in a Democracy." Journal of Political Economy 65 (2): 135-150.

Doyle, David. 2015. "Remittances and Social Spending." American Political Science Review, 109 (4): 785-802. 
Duch, Raymond M., and Randolph T. Stevenson. 2008. The Economic Vote: How Political and Economic Institutions Condition Election Results. New York: Cambridge University Press.

Escribà-Folch, Abel, Covadonga Meseguer, and Joseph Wright. 2015. "Remittances and Democratization.” International Studies Quarterly 59 (3): 571-586.

European Bank for Reconstruction and Development. 2010. Life in Transition: After the Crisis. Report by Chief Economist Erik Berglof. URL: http://www.ebrd.com/downloads/research/surveys/lits2p.pdf (accessed 11th of July 2017).

Fajnzylber, Pablo, J., Humberto Lopez. 2008. Remittances and Development: Lessons from Latin America. Washington D.C.: World Bank Publications.

Fiorina, Morris. P. 1981. Retrospective Voting in American National Elections. New Haven: Yale University Press.

Freedom House. 2010. Nations in Transit: Kyrgyzstan. Retrieved April 18, 2018 (https://freedomhouse.org/report/nations-transit/2010/kyrgyzstan).

Freedom House. 2014. Nations in Transit: Kyrgyzstan. Retrieved April 18, 2018 (https://freedomhouse.org/report/nations-transit/2014/kyrgyzstan).

Fumagalli, Matteo. 2016. "Semi-Presidentialism in Kyrgyzstan." In Semi-Presidentialism in the Caucasus and Central Asia, eds., Robert Elgie and Sophia Moestrup. London: Palgrave MacMillan, 173-205.

Germano, Roy 2010. The Political Economy of Remittances: Emigration, Social Insurance Provision, and Political Behavior in Mexico. PhD Dissertation, Department of Political Science, The University of Texas at Austin.

Germano, Roy. 2013. "Migrants' remittances and economic voting in the Mexican countryside." Electoral Studies 32 (4): 875-885.

Gomez, Brad T., and J. Matthew Wilson. 2001. "Political Sophistication and Economic Voting in the American Electorate: A Theory of Heterogeneous Attribution." American Journal of Political Science 45 (4): 899-914.

Healy, Andrew, Alexander G. Kuo, and Neil Malhotra. 2014. "Partisan Bias in Blame Attribution: When Does it Occur?" Journal of Experimental Political Science 1 (2): 144158.

International Monetary Fund. 2016. Kyrgyz Republic: Selected Issues. Washington D.C.: IMF Country Report No. 16/56.

Javeline, Debra. 2003. "The Role of Blame in Collective Action: Evidence from Russia." American Political Science Review 97 (1): 107-121.

Kayser, Mark Andreas, and Michael Peress. 2012. "Benchmarking across borders: electoral accountability and the necessity of comparison." American Political Science Review 106 (3): 661-684.

Kramer, Gerald. H. 1971. "Short-Term Fluctuations in US voting Behavior, 1896-1964." American Political Science Review 65 (1): 131-143.

Leblang, David. 2017. "Harnessing the Diaspora: Dual Citizenship, Migrant Remittances and Return." Comparative Political Studies 50 (1): 75-101.

Leigh, Andrew. 2009. "Does the World Economy Swing National Elections?" Oxford Bulletin for Economics and Statistics 71 (2): 163-181. 
Levitt, Peggy. 2001. The Transnational Villagers. Berkeley: University of California Press. Life in Transition Survey. 2006. A Survey of People's Experiences and Attitudes. European Bank for Reconstruction and Development, doi: http://www.ebrd.com/news/publications/special-reports/life-in-transition-survey-i.html.

Life in Transition Survey. 2010. After the Crisis. European Bank for Reconstruction and Development, doi: http://www.ebrd.com/downloads/research/economics/Technical_Report.pdf.

Lupu, Noam. 2016. Party Brands in Crisis: Partisanship, Brand Dilution, and the Breakdown of Political Parties in Latin America. New York: Cambridge University Press.

Manacorda, Marco, Edward Miguel, and Andrea Vigorito. 2011. "Government Transfers and Political Support.” American Economic Journal: Applied Economics 3 (1): 1-28.

Meseguer, Covadonga, Sebastián Lavezzolo, and Javier Aparicio. 2016. "Financial Remittances, Trans-Border Conversations, and the State." Comparative Migration Studies, 4 (13): 1-29.

Mohapatra, Sanket and Dilip Ratha. 2010. "The Impact of the Global Financial Crisis on Migration and Remittances." Economic Premise No. 2. Washington, DC: World Bank.

Monteiro, Joana, and Claudio Ferraz. 2012. "Does Oil Make Leaders Unaccountable? Evidence from Brazil's Offshore Oil Boom." Working Paper, Center of International Development, Harvard University.

O'Mahony, Angela. 2013. "Political Investment: Remittances and Elections." British Journal of Political Science 43 (4): 799-820.

O'Neill, Alexander C. 2001. "Emigrant Remittances: Policies to Increase Inflows and Maximize Benefits.” Indiana Journal of Global Legal Studies 9 (1): 345-360.

Orozco, Manuel, and Rebecca Rouse. 2013. "Migrant Hometown Associations and Opportunities for Development." Community Development. Washington: Migration Policy Institute 280.

Page, John and Sonia Plaza. 2006. "Migration Remittances and Development: A Review of Global Evidence." Journal of African Economies 15 (2): 245-336.

Pérez-Armendáriz, Clarisa, and David Crow. 2010. "Do Migrants Remit Democracy? International Migration, Political Beliefs, and Behavior in Mexico." Comparative Political Studies 43 (1): 119-148.

Pfutze, Tobias. 2014. "Clientelism versus Social Learning: The Electoral Effects of International Migration.” International Studies Quarterly 58 (2): 295-307.

Pop-Eleches, Cristian, and Grigore Pop-Eleches. 2012. "Targeted Government Spending and Political Preferences.” Quarterly Journal of Political Science 7 (3): 285-320.

Posner, Daniel N., and David J. Simon. 2002. "Economic Conditions and Incumbent Support in Africa's New Democracies: Evidence from Zambia." Comparative Political Studies 35 (3): 313-336.

Ratha, Dilip, Sanket Mohapatra, and Ani Silwal. 2010. "Outlook for Remittance Flows 20102011: Remittance Flows to Developing Countries Remained Resilient in 2009, Expected to Recover during 2010-2011." Migration and Development Brief 12, Washington D.C.: World Bank. 
Ratha, Dilip, Christian Eigen-Zucchi, and Sonia Plaza. 2016. Migration and Remittances Factbook 2016. Washington D.C.: World Bank Publications.

Roberts, Andrew. 2008. "Hyperaccountability: Economic Voting in Central and Eastern Europe.” Electoral Studies 27 (3): 533-546.

Singer, David Andrew. 2010. "Migrant Remittances and Exchange Rate Regimes in the Developing World." American Political Science Review 104 (2): 307-323.

Singer, David Andrew. 2012. "The Family Channel: Migrant Remittances and Government Finance." Working Paper, Department of Political Science, Massachusetts Institute of Technology.

Singer, Matthew M. 2013. "Economic Voting in an Era of Non-Crisis: The Changing Electoral Agenda in Latin America, 1982-2010.” Comparative Politics 45 (2): 169-185.

Slay, Ben. 2015. Exchange Rates, Remittances, and Poverty in the Kyrgyz Republic. UNDP. Accessible online at: http://www.eurasia.undp.org/content/rbec/en/home/presscenter/articles/2015/5/2 5/exchange-rates--remittances--and-poverty-in-the-kyrgyz-republic.html.

Snijders, Tom A.B. and Roel J. Bosker. 2012. Multilevel Analysis: An Introduction to Basic and Advanced Multilevel Modeling (Second Edition). London: Sage Publishers.

Stigler, George J. 1973. "General Economic Conditions and National Elections.” American Economic Review 63 (1): 160-167.

Stokes, Susan C. 2001. Mandates and Democracy: Neoliberalism by Surprise in Latin America. New York: Cambridge University Press.

Tyburski, Michael D. 2012. "The Resource Curse Reversed? Remittances and Corruption in Mexico.” International Studies Quarterly 56 (2): 339-350.

Vieira, Helena. 2017. Catherine Wines: "International Remittances Help People Directly" LSE Business Review. Available online at: http://blogs.lse.ac.uk/businessreview/2017/11/03/catherine-wines-internationalremittances-help-people-directly-interview/.

Wibbels, Erik. 2006. "Dependency Revisited: International Markets, Business Cycles, and Social Spending in the Developing World." International Organization 60 (2): 433-468.

Williams, John T. 1985. "Systemic Influences on Political Trust: The Importance of Perceived Institutional Performance." Political Methodology 11(1/2): 125-142.

World Bank. 2017. Dataset: World Development Indicators (April 2017). doi: https://stats.ukdataservice.ac.uk.

Yang, Dean and HwaJung Choi. 2007. "Are Remittances Insurance? Evidence from Rainfall Shocks in the Philippines." The World Bank Economic Review 21 (2): 219-248. 